\title{
Possible use of Inula viscosa (Dittrichia viscosa L.) for biostimulation of Oscularia deltoides and Corpuscolaria lehmanii plants and protection against Aphis nerii
}

\author{
Prisa Domenico * \\ CREA Research Centre for Vegetable and Ornamental Crops, Council for Agricultural Research and Economics, Via dei \\ Fiori 8, 51012 Pescia, PT, Italy.
}

Publication history: Received on 06 December 2019; revised on 16 December 2019; accepted on 17 December 2019

Article DOI: https://doi.org/10.30574/gscbps.2019.9.3.0231

\begin{abstract}
In this study the possibility of using liquid Inula viscosa (Dittrichia viscosa L.) to improve the growth and quality of Oscularia deltoides and Corpuscolaria lehmanii plants and protection against Aphis nerii was evaluated. The 3 experimental groups in cultivation were: i) group without the use of Inula viscosa liquid macerate (CTRL), irrigated with water and previously fertilised substrate; ii) group treated with 1\% of Inula viscosa liquid obtained from flowers (leaf spraying and soil irrigation), previously fertilized substrate (INU1); iii) group treated with 1\% of Inula viscosa liquid obtained from leaves and stems (leaf spraying and soil irrigation), previously fertilized substrate (INU2). The test showed a significant increase in the agronomic parameters analyzed in plants treated with liquid Inula viscosa. In fact, all plants treated with Inula showed a significant increase in plant height, leaves number, vegetative and roots weight, branches and flowers number and flowering time in both Corpuscolaria lehmanii and Oscularia deltoides. An evaluation was also made of the number of individuals of Aphis nerii present on the plants of Corpuscolaria lehmanii and Oscularia deltoides to assess whether the macerate of Inula can be used for the control of these insects. The GC-MS analysis of active fractions strongly suggested costic acid as the compound responsible for contact toxicity against Aphis nerii. Probably in the plant treated with Inula viscosa there is an induction of the defense mechanisms that lead to greater resistance to biotic and abiotic stresses. The application of Inula macerate also improves the plant's defences against attacks by fungal pathogens and insects. Very interesting aspects, especially in view of a possible reduction of fertilizers and synthetic plant protection products.
\end{abstract}

Keywords: Succulent; Stress tolerance; Plant extract; Biostimulation; Growth promoters

\section{Introduction}

The Inula viscosa (syn. Dittrichia viscosa Greuter) (family Compositae) is a perennial bushy plant, generally evergreen, the largest among the Phanerogams, which includes an estimated number of genera around 959, rather common in the Mediterranean regions [1] (Figure 1). The I. viscosa is a perennial shrub plant, with a characteristic smell, which has erect cauli, woody at the base, richly covered with leaves, with a height of between 50 and $150 \mathrm{~cm}$. The leaves, linear-lanceolate, are rough and green with the upper part richly covered with hairs and glands. The pyramidal inflorescence is composed of numerous flower heads with golden yellow flowers. Flowering takes place in autumn, while the fruits are made up of achenes. This plant has long been the subject of studies in relation to the presence in different parts of the plant (roots, stem, leaves, flowers, etc.) of numerous components of different chemical nature, whose properties make interesting some potential applications in pharmaceutical, cosmetic, aromatic, aromatic and related [2]. In fact, this species has long been known for its properties and therefore used in folk medicine essentially to treat liver disorders, such as analgesic, anti-inflammatory, antipyretic, antipyretic, anthelmintic and antifungal $[3,4]$.

\footnotetext{
${ }^{*}$ Corresponding author

E-mail address: domenico.prisa@crea.gov.it
} 
Numerous studies have been conducted to identify and isolate active compounds from its biomass. Among the most important classes of chemical compounds present within the Inula are mainly mono-, sesqui- and tri-terpenes, flavones, flavanones and carbohydrates. Both organic extracts and some metabolites showed antifungal activity towards dermatophytes and Candida albicans [5], antioxidant properties and anti-inflammatory effects in rats [6], fungicidal activity towards some pathogens of agricultural interest [7,8]. Extracts of $I$. viscosa showed antifungal activity for phytopathogenic fungi and secondary plant metabolites, are known to have insecticidal, antifungal, acaricidal, antibacterial and cytotoxic activity $[6,8]$.

Experimental evidence shows that Inula extract can be used in the control of varroa and nosema in bees, introduced into gel blocks and exploiting olfactory disorientation $[9,10,11]$.

In this study the possibility of using liquid Inula viscosa (Dittrichia viscosa L.) to improve the growth and quality of Oscularia deltoides and Corpuscolaria lehmanii plants and protection against Aphis nerii was evaluated.

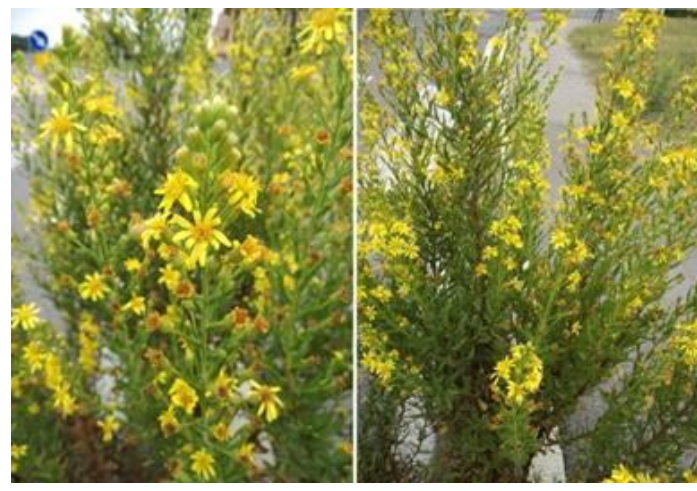

Figure 1 Details of Inula viscosa plants

\section{Material and methods}

\subsection{Greenhouse experiment and growing conditions}

The experiments, started at the beginning of February 2019, were conducted in the greenhouses CREA-OF of Pescia (Pt), Tuscany, Italy $\left(43^{\circ} 54^{\prime} \mathrm{N} 10^{\circ} 41^{\prime} \mathrm{E}\right)$ on plants Oscularia deltoides and Corpuscolaria lehmanii. The plants were placed in pots $\emptyset 12 \mathrm{~cm} ; 60$ plants for each experimental thesis, divided into 3 replicas of 20 plants each. All plants were fertilized with a controlled release fertilizer $(2 \mathrm{~kg} \mathrm{~m}-3$ Osmocote Pro® 6 months with 190 g/kg N, 39 g/kg P, 83 g/kg $\mathrm{K})$ mixed with the culture medium before transplanting. The 3 experimental groups in cultivation were:

- $\quad$ group without the use of Inula viscosa liquid macerate (CTRL), irrigated with water and previously fertilised substrate;

- $\quad$ group treated with 1\% of Inula viscosa liquid obtained from flowers (leaf spraying and soil irrigation), previously fertilized substrate (INU1);

- $\quad$ group treated with 1\% of Inula viscosa liquid obtained from leaves and stems (leaf spraying and soil irrigation), previously fertilized substrate (INU2).

The treatments with Inula were carried out every 15 days during the entire cultivation cycle. The plants were watered twice a week and grown for 9 months. The plants were irrigated with drip irrigation. The irrigation was activated by a timer whose program was adjusted weekly according to climatic conditions and the fraction of leaching. On November 25,2019 , the plant height, the leaves number, the vegetative and radical weight, the branches and flowers number, the total fresh weight and total dry weight, the duration of flowering were recorded. The number of individuals of Aphis nerii on the plants was also counted to assess whether Inula viscosa could determine a control on these insects.

\subsection{Isolation of the essential oil of Inula viscosa}

Fresh samples of leaves and flowers $(1 \mathrm{~kg}$ ) were hydrodistilled for $3 \mathrm{~h}$ using a modified Clevenger-type apparatus [12]. The oils obtained were recovered with hexane, dried over anhydrous sodium sulfate, concentrated with nitrogen and stored at $-4{ }^{\circ} \mathrm{C}$ until analysis. 
$100 \mathrm{~g}$ of flowers were set in a glass column and extracted by percolation with dichloromethane for $1 \mathrm{~h}$. $100 \mathrm{ml}$ of extract were recovered and evaporated to dryness under vacuum in a rotavapor. The residue was redissolved in methanol/water (8:2) and extracted with hexane to remove chlorophyll. The aqueous phase was evaporated under vacuum [13].

\subsection{Quantitative and qualitative analyses of Inula viscosa}

Quantitative and quantitative analyses (area \%) were performed by Shimadzu GC/MS GC-17A Gas Chromatograph with QP5000 Mass Spectrometer.

\subsection{Preparation of Inula viscosa macerate}

The plants of Inula viscosa have been taken in the countryside of Rosignano Solvay (LI). For the maceration of the flowers, $2 \mathrm{Kg}$ of fresh flowers were placed in $25 \mathrm{~L}$ of water, maceration for 20 days at $32^{\circ} \mathrm{C}$. For the maceration of leaves and stems, $2 \mathrm{Kg}$ of fresh plant material were placed in $25 \mathrm{~L}$ of water, maceration for 20 days at $32^{\circ} \mathrm{C}$. From the $25 \mathrm{~L} \mathrm{of}$ macerate obtained (flowers, leaves/stems), 1L was placed in 100 litres of water. For each treatment, carried out every 15 days for the entire cultivation cycle, $350 \mathrm{ml}$ per plant (spraying and irrigation) of the 1:100 dilution were used.

\subsection{Statistics}

The experiment was carried out in a randomized complete block design. Collected data were analysed by one-way ANOVA, using GLM univariate procedure, to assess significant $(P \leq 0.05,0.01$ and 0.001$)$ differences among treatments. Mean values were then separated by LSD multiple-range test $(P=0.05)$. Statistics and graphics were supported by the programs Costat (version 6.451) and Excel (Office 2010).

\section{Results}

The test showed a significant increase in the agronomic parameters analyzed in plants treated with liquid Inula viscosa. In fact, all plants treated with Inula showed a significant increase in plant height, leaves number, vegetative and roots weight, branches and flowers number and flowering time in both Corpuscolaria lehmanii and Oscularia deltoides. In Corpuscolaria lehmanii, (Table 1) the plants height was $10.63 \mathrm{~cm}$ (INU1), compared to 9,25 cm (INU2) and $7,78 \mathrm{~cm}$ (CTRL). For the leaves number, 50.83 (UNI1), 43.00 (UNI2) and 22.67 (CTRL). There was a significant increase in vegetative biomass in $44.05 \mathrm{~g}$ (INU1) and $33.07 \mathrm{~g}$ (INU2), compared to $29.27 \mathrm{~g}$ in the untreated control (Figure 2A). The same trend applies to the root weights $26.20 \mathrm{~g}$ in (INU1), $22.27 \mathrm{~g}$ in (INU2) and $20.17 \mathrm{~g}$ in (CTRL) (Figure 3A). The theses with Inula viscosa then showed a significant increase in the bramches number, 25.00 (INU1) against 20.50 (INU2) and 13.50 in the untreated control. There were no significant differences in the flowers number for (INU2) 40.17 and control (CTRL) 36.33, while the macerate (INU1) significantly increased with 53.00 flowers. The same for flowering time, where there are no significant differences between (INU2) 4.00 days and control (CTRL) 3.67 days, while treatment with (INU1) significantly prolonged flowers duration, 5.57 days.

Table 1 Evaluation of the effect of macerate of Inula viscosa on plants of Corpuscolaria lehmanii

\begin{tabular}{|c|c|c|c|c|c|c|c|}
\hline Groups & $\begin{array}{c}\text { Plant } \\
\text { height } \\
\text { (cm) }\end{array}$ & $\begin{array}{c}\text { Leaves } \\
\text { number } \\
\left(n^{\circ}\right)\end{array}$ & $\begin{array}{c}\text { Vegetative } \\
\text { weight } \\
\text { (g) }\end{array}$ & $\begin{array}{c}\text { Root weight } \\
\text { (g) }\end{array}$ & $\begin{array}{c}\text { Branches } \\
\text { number } \\
\left(n^{\circ}\right)\end{array}$ & $\begin{array}{c}\text { Flower } \\
\text { number } \\
\left(n^{\circ}\right)\end{array}$ & $\begin{array}{c}\text { Flowering } \\
\text { time } \\
\text { (days) }\end{array}$ \\
\hline CTRL & $7.78^{c}$ & $22.67^{c}$ & $29.27 \mathrm{c}$ & $20.17^{c}$ & $13.50^{c}$ & $36.33 \mathrm{~b}$ & $3.67 \mathrm{~b}$ \\
\hline INU1 & $10.63^{a}$ & $50.83^{a}$ & $44.05^{\mathrm{a}}$ & $26.20^{a}$ & $25.00^{a}$ & $53.00^{a}$ & $5.67^{\text {a }}$ \\
\hline INU2 & $9.25^{b}$ & $43.00^{b}$ & $33.07^{b}$ & $22.27^{b}$ & $20.50^{b}$ & $40.17^{b}$ & $4.00^{b}$ \\
\hline ANOVA & $* * *$ & $* * *$ & $* * *$ & $* * *$ & $* * *$ & $* * *$ & $* * *$ \\
\hline
\end{tabular}

One-way ANOVA; n.s. - non significant; ${ }^{*}, * * * * *$ - significant at $\mathrm{P} \leq 0.05,0.01$ and 0.001 , respectively; different letters for the same element indicate significant differences according to Tukey's (HSD) multiple-range test $(\mathrm{P}=0.05)$

Even in Oscularia deltoides (Table 2), the plants height was $35.50 \mathrm{~cm}$ (INU1), compared to $30.77 \mathrm{~cm}$ (INU2) and 16.77 $\mathrm{cm}$ (CTRL). For the leaves number, 51.00 (INU1), while there are no significant differences between (INU2) 43.33 and the control (CTRL), 41.00. Also for vegetative biomass there was a significant increase in (INU1) $44.18 \mathrm{~g}$ and (INU2) $36.42 \mathrm{~g}$, compared to $30.30 \mathrm{~g}$ of the untreated control (Figure 2B). The same trend for roots weight, with $29.97 \mathrm{~g}$ (INU1), $24.52 \mathrm{~g}$ (INU) and $16.83 \mathrm{~g}$ in the control (Figure 3B). The theses with Inula viscosa, also in Oscularia deltoides showed a significant increase in both the branches number, 53.33 (INU1) against 35.33 (INU2) and 14.83 in the untreated control and in the flowers number, 69.00 (INU1), 49.00 (INU2) and 24.33 for the control. 
There are no significant differences in flowering time for (INU2) 3.83 days and control 3.50 days, while treatment with (INU1) significantly increased the flowering time with 4.67 days.

Table 2 Evaluation of the effect of macerate of Inula viscosa on plants of Oscularia deltoids

\begin{tabular}{|c|c|c|c|c|c|c|c|}
\hline Groups & $\begin{array}{c}\text { Plant } \\
\text { height } \\
\text { (cm) }\end{array}$ & $\begin{array}{c}\text { Leaves } \\
\text { number } \\
\left(n^{\circ}\right)\end{array}$ & $\begin{array}{c}\text { Vegetative } \\
\text { weight } \\
\text { (g) }\end{array}$ & $\begin{array}{c}\text { Root } \\
\text { weight } \\
\text { (g) }\end{array}$ & $\begin{array}{c}\text { Branches } \\
\text { number } \\
\left(n^{\circ}\right)\end{array}$ & $\begin{array}{c}\text { Flower } \\
\text { number } \\
\left(n^{\circ}\right)\end{array}$ & $\begin{array}{c}\text { Flowering } \\
\text { time } \\
\text { (days) }\end{array}$ \\
\hline CTRL & $16.77^{c}$ & $41.00^{b}$ & $30.30^{c}$ & $16.83^{c}$ & $14.83^{c}$ & $24.33^{c}$ & $3.50^{b}$ \\
\hline INU1 & $35.50^{a}$ & $51.00^{\mathrm{a}}$ & $44.18^{\mathrm{a}}$ & $29.97^{a}$ & $53.33^{\mathrm{a}}$ & $69.00^{\mathrm{a}}$ & $4.67^{a}$ \\
\hline INU2 & $30.77^{b}$ & $43.33^{b}$ & $36.42^{b}$ & $24.52 \mathrm{~b}$ & $35.33^{b}$ & $49.00^{b}$ & 3.83 b \\
\hline ANOVA & $* * *$ & $* * *$ & $* * *$ & $* * *$ & $* * *$ & $* * *$ & $* *$ \\
\hline
\end{tabular}

One-way ANOVA; n.s. - non significant; ${ }^{*}{ }^{* *},{ }^{* * *}$ - significant at $\mathrm{P} \leq 0.05,0.01$ and 0.001 , respectively; different letters for the same element indicate significant differences according to Tukey's (HSD) multiple-range test $(P=0.05)$
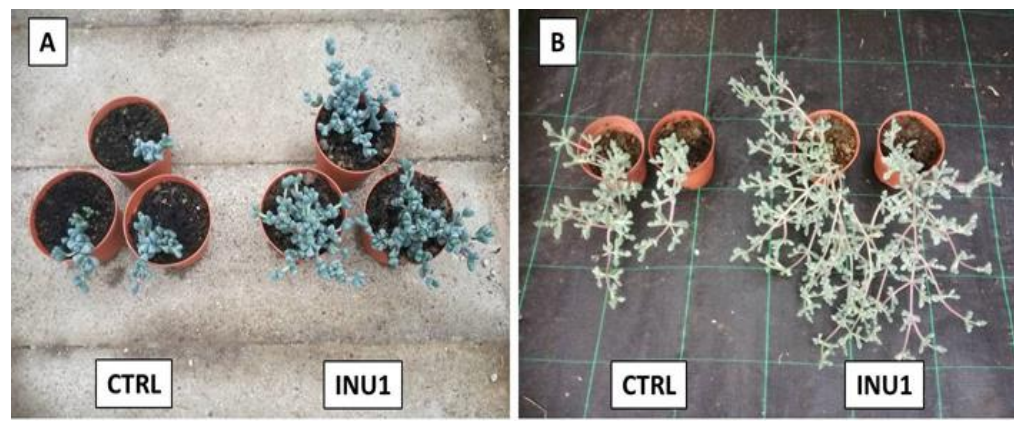

Figure 2 Effect of Inula viscosa on vegetative biomass of Corpuscolaria lehmanii (A) and Oscularia deltoides (B)

Legend: (CTRL) control; (INU1) Inula viscosa 1\%
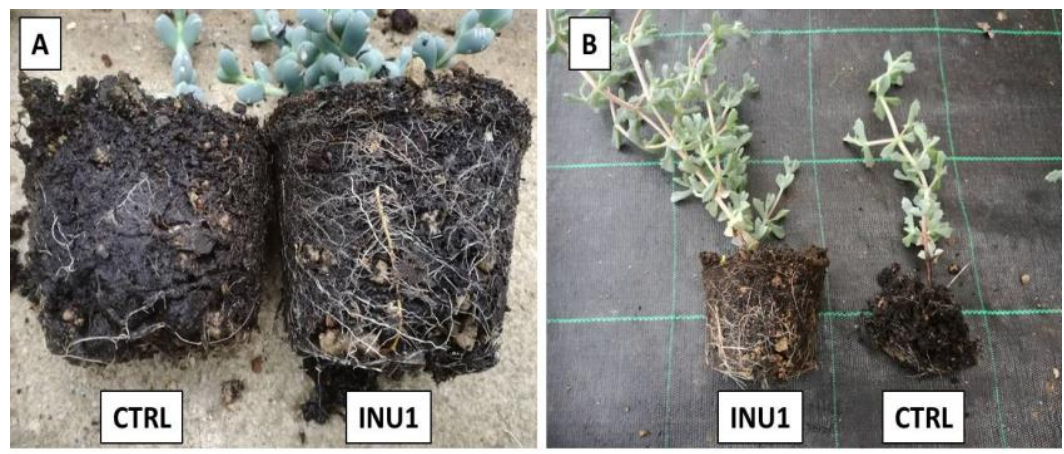

Figure 3 Effect of Inula viscosa on roots biomass of Corpuscolaria lehmanii (A) and Oscularia deltoides (B)

Legend: (CTRL) control; (INU1) Inula viscosa 1\%

An evaluation was also made of the number of individuals of Aphis nerii present on the plants of Corpuscolaria lehmanii and Oscularia deltoides to assess whether the macerate of Inula can be used for the control of these insects (Table 3). On the plants of Corpuscolaria lehmanii, 18,83 individuals of Aphis nerii were found in the control, 12,33 in (INU2) and 6,83 in (INU1). Same trend on the plants of Oscularia deltoides where 12.67 individuals were found in the control, while there are no significant differences between (INU1) and (INU2), with 4.17 and 5.67 respectively.

In total, adding up the number of Aphis nerii found on plants, there are 189 individuals in the control, 66 in (INU1) and 108 in (INU2). 
Table 3 Evaluation of the number of Aphis nerii on plants of Corpuscolaria lehmanii and Oscularia deltoids

\begin{tabular}{cccc}
\hline Groups & $\begin{array}{c}\text { Corpuscolaria } \\
\text { lehmanii }\end{array}$ & $\begin{array}{c}\text { Oscularia } \\
\text { deltoides }\end{array}$ & $\begin{array}{c}\text { Total } \\
\text { Aphis nerii number }\end{array}$ \\
\hline CTRL & $18.83^{\text {a }}$ & $12.67^{\mathrm{a}}$ & 189 \\
INU1 & $6.83^{\mathrm{c}}$ & $4.17^{\mathrm{b}}$ & 66 \\
INU2 & $12.33^{\mathrm{b}}$ & $5,67^{\mathrm{b}}$ & 108 \\
\hline ANOVA & $* * *$ & $* * *$ & -
\end{tabular}

One-way ANOVA; n.s. - non significant; ${ }^{*}, * * * * *-$ significant at $\mathrm{P} \leq 0.05,0.01$ and 0.001 , respectively; different letters for the same element indicate significant differences according to Tukey's (HSD) multiple-range test $(\mathrm{P}=0.05)$

The gas chromatographic analysis (Table 4) revealed a higher content of metabolites in Inula flowers than in stems and leaves. This high content of metabolites, in particular monoterpenes and isocostic acid, could be the basis for the plant's ability to repel/insecticide insects, an aspect also highlighted in the control of bee varroa in the form of gels. In addition, the trial also shows the biostimulating properties of maceration of the flowers and leaves/stem of this plant. This is particularly interesting for improving the quality characteristics and stress resistance of cultivated plants, particularly succulent plants.

Table 4 Essential oils of leaves and flowers of Inula viscosa taken from the countryside of Rosignano Solvay (LI)

\begin{tabular}{|c|c|c|}
\hline Components & Flowers & Leaves/stems \\
\hline Isocostic acid & 33.23 & 52.34 \\
\hline$\alpha$-Pinene & 0.30 & - \\
\hline Eucalyptol & 3.45 & 0.13 \\
\hline$\beta$-Linalool & 1.37 & 0.14 \\
\hline Nonanal & 0.60 & 0.45 \\
\hline 1-Terpineol & 0.22 & 1.13 \\
\hline Eugenol & 3.33 & 0.26 \\
\hline$(+) \alpha$-Terpineol & 3.21 & 0.34 \\
\hline$\beta$-Caryophyllene & 1.15 & 0.63 \\
\hline Valencene & 1.44 & 0.16 \\
\hline Ylangene & 0.25 & 0.12 \\
\hline Benzyl benzoate & 0.38 & 0.55 \\
\hline$\alpha$-Eudesmol & 1.56 & 1.44 \\
\hline Methyl palmitate & 0.70 & 0.15 \\
\hline Phytol & 2.00 & 1.20 \\
\hline Tomentosin & 0.46 & 0.62 \\
\hline 12-Carboxyeudesma- & 25.66 & 34.67 \\
\hline 3,11(13)diene & 1.88 & 3.46 \\
\hline Selina6en 4 ol & 2.28 & 0.17 \\
\hline Linoleic acid ethyl ester & 2.71 & 0.78 \\
\hline Docosane/tricosane & 8.66 & 0.80 \\
\hline Monoterpenes & 6.76 & 4.21 \\
\hline Hydrocarbon sesquiterpenes & 1.81 & 1.04 \\
\hline Oxygenated compounds & 4.56 & 0.79 \\
\hline Fatty acids & 3.89 & 3.22 \\
\hline Total & 111.86 & 108.80 \\
\hline
\end{tabular}




\section{Discussion}

The use of Inula viscosa liquid macerate can stimulate the growth of the plants, increase the blooms and the flowering time of Corpuscolaria lehmanii and Oscularia deltoides.

A high variability in the qualitative and quantitative composition of the metabolites produced was observed, depending on the soil and climate conditions, the geographical area of origin and the phenological stage of the plant itself [14]. Among the most typical metabolites of this species are sesquiterpenic acids and the corresponding lactones. These are further subdivided into three subclasses of compounds such as eudesmanolids, guaianolids and germacranolids [2]. Among these, acid- $\alpha$-costic showed different activities while sesquiterpenes, tomentosin and inuviscolide induced apoptosis of human melanoma cells [15] as well as showing anti-inflammatory, antioxidant, antibacterial and antimycotic activity [16]. Among the most significant phytosterols isolated and identified both from the aerial part and from the roots are stimulasterols, $\beta$-sitosterols and tarassasterols $[17,18]$. The GC-MS analysis of active fractions strongly suggested costic acid as the compound responsible for contact toxicity against Aphis nerii.

Probably in the plant treated with Inula viscosa there is an induction of the defense mechanisms that lead to greater resistance to biotic and abiotic stresses.

Numerous studies of I. viscosa extracts have shown antifungal activity for phytopathogenic fungi and secondary plant metabolites, they are known to have insecticidal, antifungal, acaricidal, antibacterial and cytotoxic activity [6,8]. This test also shows biostimulating effects in terms of vegetative and radical growth of plants and improvement of flowering. Very interesting aspects that make Inula viscosa a possible alternative to be used as a liquid biostimulant and in the control of insects and pathogenic fungi.

\section{Conclusion}

The test has shown that the use of a liquid biostimulant obtained from Inula viscosa can significantly improve the growth and quality of Corpuscolaria lehmanii and Oscularia deltoides. The application of Inula macerate also improves the plant's defences against attacks by fungal pathogens and insects. Very interesting aspects, especially in view of a possible reduction of fertilizers and synthetic plant protection products.

\section{Compliance with ethical standards}

\section{Acknowledgments}

The research is part of the project "Micronaturale": innovative techniques with low environmental impact for the cultivation and protection of plants.

\section{Disclosure of conflict of interest}

The author declares no conflict of interest.

\section{References}

[1] Zermane N, Vurro M, Boari A, Avolio F, Andolfi A and Evidente A. (2011). Towards broomrape and field dodder management using natural metabolites from plants. Abstract of 11th World Congress on Parasitic Plants, 82

[2] Cum G, Spadaro A, Citraro T and Gallo R. (2001). Inula viscosa (L.) Aiton. - Part2: Extraction process and chemical characterization of the essential oil. Essenze e Derivati Agrumari.

[3] Chiappini I, Fardella G, Menghini A and Rossi C. (1982). Flavonoids from Dittrichia viscosa. Planta Med., 44, 159-161.

[4] Wollenweber E, Mayer K and Roitman JN. (1991). Exudates flavonoids of Inula viscosa. Phytochemistry, 30, 2445-2446.

[5] Maoz M and Neeman I. (2000). Effect of Inula viscosa extract on chitin synthesis in dermatophytes and Candida albicans. J. Ethnopharmacol., 71, 479-482. 
[6] Schinella GR, Tournier HA, Priero JM, De Buschiazzo M and Ríos JL. (2002). Antioxidant activity of antiinflammatory plant extracts. Life Sci., 70, 1023-1033.

[7] Wang W, Ben-Daniel BH and Cohen Y. (2004). Control of plant diseases by extracts of Inula viscosa. Dis. Control Pest Manage, 94, 1042-1047.

[8] Hernández V, Recio MC, Máñez, S, Giner RM and Ríos, JL. (2007). Effects of naturally occurring dihydro flavonols from Inula viscosa on inflammation and enzymes involved in the arachidonic acid metabolism. Life Sci., 81, 480488.

[9] Prisa D. (2016). Ritorno alle origini. Microrganismi EM, protocolli ed esperienze per un'apicoltura sostenibile. Apinsieme ottobre, 28-34.

[10] Prisa D. (2017). Apicoltura biologica metodi innovativi naturali e difesa delle api. (parte 1) Apinsieme Aprile, 42-45.

[11] Prisa D. (2017). Apicoltura biologica metodi innovativi naturali e difesa delle api. (parte 2) Apinsieme Maggio, 42-45.

[12] Perez-Alonso MJ, Velasconeguerela A, Duru ME, Harmandar M and Garcia-Vallejo MC. (1996). Flavour Fragr. J, $11,349$.

[13] De Laurentis N, Losacco V, Milillo MA and Lai O. (2002). Chemical investigations of volatile constituents of Inula viscosa (L.) Aiton (Asteraceae) from different areas of Apulia, Southern Italy. Delpinoa, 44, 115-119.

[14] Mueller-Riebau FJ, Berger BM and Yegen O. (1995). Chemical-composition and fungitoxic prpoerties to phytopathogenic fungi of essential oil of selected aromatic plants growing wild in Turkey. J. Agr. Food Chem., $43,2262-2266$.

[15] Rozenblat S, Grossman S, Bergman M, Gottlieb H, Cohen Y and Dovrat S. (2008). Induction of G2/M arrest and apoptosis by sesquiterpene lactones in human melanoma cell lines. Biochem. Pharmacol., 75, 369-382.

[16] Gayla A, Dovrat S, Bessler H, Grossman S, Nir U and Bergman M. (2010). Inhibition of infiammatory cytokine secretion by plant-derived compounds inuviscolide and tomentosin: the role of NFkB and STAT1. Open Pharmacol. J., 4, 36-44.

[17] Oksuz S. (1976). Ч-Taraxasterol acetate from Inula viscosa. Planta Med., 29, 343-345.

[18] Simoes F and Nascimento J. (1990). Constituents of Dittrichia viscosa subsp. Viscosa. Fitoterapia, 61, 553-554.

\section{How to cite this article}

Prisa D. (2019). Possible use of Inula viscosa (Dittrichia viscosa L.) for biostimulation of Oscularia deltoides and Corpuscolaria lehmanii plants and protection against Aphis nerii. GSC Biological and Pharmaceutical Sciences, 9(3), 6975. 